\section{Germany uses BSE fears to seek ban on British beef}

Munich. German scientists are split over efforts being made by the country's health minister, Horst Seehofer, to secure a Europe-wide ban on the import of British beef on the basis that it could be infected with bovine spongiform encephalopathy (BSE).

The German minister's proposal is based on concern that the disease, which first broke out among cattle in the mid-1980s and causes fatal neurological symptoms similar to those associated with the human Creutzfeldt-Jakob disease (CJD), could be transferred to humans through the consumption of meat.

Last week, acting on a recommendation from the Bundesgesundheitsamt (BGA), the German federal health agency, Seehofer suggested to his fellow European health ministers that the European Commission (EC) impose a ban on the import of British beef by all countries of the European Union (EU).

BGA scientists say the possibility of cross-species disease transfer has not been positively disproved, and that evidence of a few cases of BSE-like syndrome in zoo animals has raised new concerns.

But Hans-Dieter Klenk, a virologist from the Marburg Institute for Virology and one of five independent scientists who took part in a meeting organized by the BGA last December to discuss what action Germany should take in the light of public fears about British beef - and who concluded that there was "no scientific finding that BSE is transferable to humans" - says that a ban is "too early".

Seehofer's actions are based on the fact that the current BSE epidemic in Britain has almost certainly been caused by the practice of feeding cattle with a mix containing the brains of sheep suffering from a similar disease, scrapie (a practice stopped in 1988).

The epidemic is being checked in Britain by slaughtering infected herds, and imposing stringent controls to ensure that all beef intended for consumption is free from nervous tissue and other potentially infected offal. British government scientists claim these controls are sufficient to protect the public. "The facts are clear," says Ray Bradley from Britain's Central Veterinary Laboratory in Weybridge. "There is no evidence anywhere in the world that diseases of the spongiform encephalopathy group can be transferred naturally through meat consumption."

Despite this, Seehofer is now trying to convince his EU partners that they should adopt the German recommendation for a ban on British beef. He and other members of the German cabinet - in a move supported by the German parliament - is now planning to push for agreement in two fur- ther meetings later this month in Brussels.

Seehofer has also said that if a Europewide ban is not imposed by the commission, Germany will impose its own national ban on British beef. But there is a wide perception in Germany that his position has more to do with politics than with science.

Last year, Seehofer ordered the disbanding of the BGA because, he said, it was not keeping him sufficiently informed of important health threats, and in particular had not alerted him to incidences of HIV-contaminated blood. In an election year, many observers feel that he is reacting strongly to the purported health risk from BSE in order

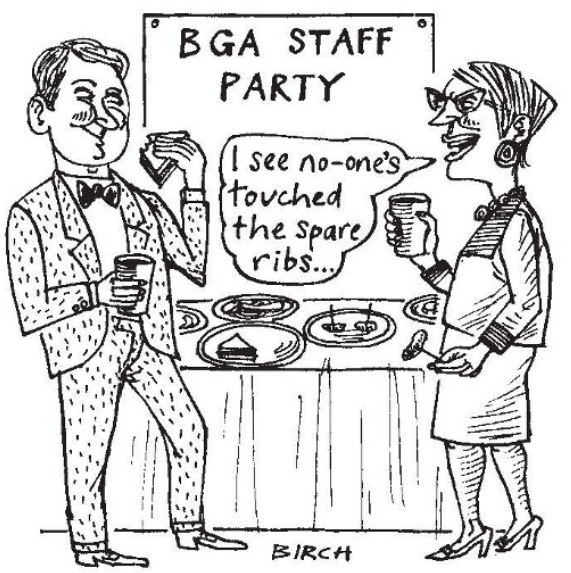

to promote his own credibility and that of his party, the Christian Democrats.

So far, Seehofer has been unable to convince the $\mathrm{EC}$ of the merits of his case. The commission is backing the claims of the British government that the risks from British beef are negligible.

Alison Abbott
London. The number of strategic alliances between European biotechnology companies is likely to more than double over the next five years, according to a survey published this week by the consultants Ernst \& Young Europe.

Unveiling the results of the company's first survey of the European biotechnology scene, Europe Biotech 94: A new industry emerges, Pieter Lucas, a consultant to the company, revealed that Europe has 386 biotechnology start-up companies, with the United Kingdom accounting for a third of them. All are building up their strategies to meet growth in the global marketplace, said Lucas. "CEOs [chief executive officers] expect alliances with pharmaceutical companies to increase by 50 per cent over the next five years. Alliances with European agricultural companies are expected to remain constant, while alliances with US ag-

\title{
Delayed pay rises still leave concerns in Hungary
}

Budapest. Scientists in Hungary have at last received a 30 per cent salary increase promised by the government in a law approved two years ago covering working conditions for all civil servants.

But concern remains at the way in which the law provides guaranteed positions to all scientists in government-funded research institutes, at a time when the Hungarian Academy of Sciences is trying to introduce more flexible employment practices.

The law was passed in 1992, but only took effect this year. Last autumn, concerned at the costs of a substantial increase in the salaries of all public employees, the government tried to renegotiate the new pay scales. It backed down after a protest from civil servants, including health workers, teachers and research scientists.

But it seems that the increases will cover only minimum wages, not the additional bonuses promised to scientists. Bonuses are paid to individuals who, for example, speak foreign languages or handle dangerous chemicals. They are often vital to scientists whose monthly wages average only US $\$ 300$.

Even though the issue of increased pay has been resolved, the more difficult problem remains of how the scientific community should handle the government's promise to provide secure posts for all researchers working for the Academy of Sciences.

Pál Venetianer, director of the academy's Biological Research Institute in Szeged, southern Hungary, says that short-term positions as postdoctoral research workers must be provided by academy institutes if a flexible system of working is to be developed.

Alison Abbott

\section{Biotechnology alliances set to double}

ricultural companies are expected to increase threefold."

$\mathrm{He}$ added that CEOs are placing strong emphasis on receiving advance fees and royalty percentages from alliance partners. Even more important, however, is the structuring of collaborative research and development arrangements.

The survey showed that there is virtually a consensus on near-term strategic goals. The priorities are the acquisition of new products ( 40 per cent of respondents) and the strengthening of alliances with universities ( 38 per cent of companies surveyed).

Europe's biotechnology sector is already thinking about second-generation products, with over a third saying they are looking for opportunities to license in new technology. A similar number say that licensing rights to specific applications are high on the agenda.

Mike Ward 